\title{
Application of photodynamic therapy with the use of superluminescent light-emitting diode (sLED) lamp in actinic keratosis
}

\section{Zastosowanie terapii fotodynamicznej z użyciem pulsacyjnej superluminescencyjnej lampy sLED $w$ rogowaceniu słonecznym}

\author{
Joanna Bartosińska', Agnieszka Gerkowicz', Marta Niewiedzioł², Paulina Szczepanik-Kułak', Mirosław Kwaśny³, \\ Dorota Krasowska'
}

\author{
'Department of Dermatology, Venereology and Paediatric Dermatology, Medical University of Lublin, Poland \\ 2Dermatology, Venereology and Paediatric Dermatology Clinic, the Independent Clinical Hospital No. I (SPSK I) in Lublin, Poland \\ IInstitute of Optoelectronics, the Jarosław Dąbrowski Military University of Technology, Warsaw, Poland \\ 'Klinika Dermatologii, Wenerologii i Dermatologii Dziecięcej Uniwersytetu Medycznego w Lublinie, Polska \\ 2Klinika Dermatologii, Wenerologii i Dermatologii Dziecięcej Samodzielnego Publicznego Szpitala Klinicznego Nr I w Lublinie, Polska \\ ${ }^{3}$ Instytut Optoelektroniki Wojskowej Akademii Technicznej im. Jarosława Dąbrowskiego w Warszawie, Polska
}

\author{
CORRESPONDING AUTHOR/ \\ ADRES DO KORESPONDENCJI: \\ dr hab. Joanna Bartosińska \\ Klinika Dermatologii, \\ Wenerologii \\ i Dermatologii Dziecięcej \\ Uniwersytet Medyczny \\ ul. Staszica 16 \\ 20-081 Lublin \\ tel.: +48602724 298 \\ e-mail: jbartosinski@gmail.com
}

\begin{abstract}
Introduction. Actinic keratosis is a chronic disease that often requires many treatment cycles. The choice of a treatment method depends on the thickness and number of lesions as well as their extent. An efficient method of treatment, especially in the case of superficial and moderately thick lesions, is photodynamic therapy.

Objective. Assessment of the photodynamic therapy with the use of a superluminescent light-emitting diode lamp after previous application of 5-aminolevulinic acid based on the observations of selected cases of patients with actinic keratosis.
\end{abstract}

Material and methods. The study included patients diagnosed with actinic keratosis. After debridement of scales and crusts from the affected skin area $16 \% 5$-aminolevulinic acid cream was applied. The irradiation was performed with the use of the superluminescent light-emitting diode matrix illuminator Medlight that sent out pulsed red light. The clinical evaluation was carried out before, immediately after the procedure as well as after 1 and 3 weeks.

Results. In one case, after many years of ineffective treatment with a cryosurgery, the treatment with application of superluminescent light-emitting diode therapy lead to disease remission. In the second case early therapy with the superluminescent light-emitting diode lamp lead to complete resolution of lesions. In the case of a patient with disseminated actinic keratosis, lesion-directed therapy was possible.

Conclusions. Observation results indicate a beneficial effect of superluminescent light-emitting diodes and no recurrence of actinic keratosis lesions in 3 months after the procedure. 


\section{STRESZCZENIE}

Wprowadzenie. Rogowacenie słoneczne (actinic keratosis) jest przewlekłą chorobą, która niejednokrotnie wymaga wielu cykli leczenia. Wybór metody zależy od grubości i liczby ognisk chorobowych, a także ich rozległości. Skutecznym postępowaniem, szczególnie w przypadku zmian powierzchownych i średniej grubości, jest terapia fotodynamiczna.

Cel pracy. Ocena terapii fotodynamicznej z użyciem pulsacyjnej superluminescencyjnej lampy po wcześniejszej aplikacji kwasu 5-aminolewulinowego na podstawie własnych obserwacji dotyczących wybranych przypadków pacjentów z rogowaceniem słonecznym.

Materiał i metody. Do badania zakwalifikowano pacjentów z rogowaceniem słonecznym. Po odwarstwieniu łusek i strupów z powierzchni zmienionej chorobowo skóry nakładano krem z kwasem 5-aminolewulinowym o stężeniu 16\%. Do naświetlania zastosowano źródło światła oparte na matrycach sLED firmy Medlight zapewniające pulsacyjny tryb pracy. Ocenę kliniczną przeprowadzano przed zabiegiem, zaraz po zabiegu oraz po tygodniu i 3 tygodniach.

Wyniki. W jednym przypadku po wieloletnim nieskutecznym leczeniu metodą kriochirurgiczną pacjent uzyskał remisję po zastosowaniu terapii z użyciem lampy sLED. W drugim przypadku wcześnie rozpoczęta terapia lampą sLED okazała się całkowicie skuteczna. W przypadku $3 \mathrm{u}$ pacjentki z rozsianymi ogniskami rogowacenia słonecznego, możliwe było zastosowanie naświetlania lampą sLED po punktowym nałożeniu preparatu kwasu 5-aminolewulinowego na poszczególne zmiany. Wnioski. Wyniki obserwacji wskazują na korzystny efekt terapii fotodynamicznej z użyciem lampy sLED i brak nawrotu rogowacenia słonecznego po 3 miesiącach od zabiegu.

Key words: photodynamic therapy, actinic keratosis, LED.

Słowa kluczowe: terapia fotodynamiczna, rogowacenie słoneczne, LED.

\section{INTRODUCTION}

Actinic keratosis (AK) being an early form of spinocellular carcinoma is most often found in areas exposed to ultraviolet irradition. It develops more frequently in men and individuals with phototype 1 and 2 according to Fitzpatrick's scale. After the age of 80, likelihood of developing AK is six times higher as compared with individuals aged 50-59 [1]. It may appear as a single focus or, more often, in the form of numerous lesions found on the skin of the nose, fronto-parietal region top of the head, forearms, and the back of arms. The disease course involves keratinocyte dysplasia that starts with cells in the basal layer of epidermis, what initially leads to appearance of poorly visible wide erythematous spots, which in turn may evolve into thick hyperkeratotic plaques [2].

Diagnosis of AK is usually made on the basis of medical history, as well as inspection and palpation of skin lesions. In disputable cases and the ones when

\section{WPROWADZENIE}

Rogowacenie słoneczne (actinic keratosis - AK), wczesna postać raka kolczystokomórkowego (carcinoma spinocellulare in situ), najczęściej zajmuje okolice narażone na działanie promieni ultrafioletowych. Występuje częściej u mężczyzn niż u kobiet oraz częściej u osób z fototypem I i II wg klasyfikacji Fitzpatricka niż z wyższymi fototypami. Prawdopodobieństwo rozwoju AK jest sześć razy wyższe u osób po 80. roku życia niż u osób w wieku 50-59 lat [1]. Choroba może występować jako pojedyncze ognisko lub częściej w postaci licznych zmian zlokalizowanych na skórze nosa, okolicy czołowo-ciemnieniowej, szczytu głowy oraz przedramion i grzbietów rąk. W przebiegu schorzenia dochodzi do dysplazji keratynocytów rozpoczynającej się od komórek warstwy podstawnej naskórka, co prowadzi początkowo do powstania słabo widocznych plam rumieniowych o szorstkiej powierzchni, które następnie mogą ewoluować do grubych, hiperkeratotycznych blaszek [2]. 
invasive forms are suspected, results of histopathological examinations are the most important. Currently, dermoscopic methods play an important diagnostic role. Zalaudek et al. [3] observed a correlation between a clinical AK severity as classified by Olsen et al. [4] and a dermoscopic picture. Thin lesions, grade 1, are characterized by a red pseudo-network. In case of clinical lesions that are assessed as grade 2 in dermoscopy, a so-called "strawberry pattern" may be observed, whereas in grade 3 - structurless white-yellow areas [3].

Actinic keratosis is a chronic skin disease that often requires many treatment cycles, and the choice of a method depends on the thickness and number of disease foci as well as their extent [5]. Development of spinocellular carcinoma depends on the level of postsun damage and its duration [1]. It is estimated that an annual risk of an individual AK sun damage becoming a malignancy amounts to $0.025-16 \%$. It is significantly higher in cases of numerous foci, especially when they cover the skin surface extensively [6].

Photodynamic therapy is an established and effective method especially in case of superficial and medium-thick lesions. Its mechanism is based on using photosensitizers that accumulate in abnormal cells, and then become activated by light with appropriate wavelength that contributes to generation of reactive oxygen species, including singlet oxygen. It leads to changes in microcirculation, appearance of local inflammatory reaction and death of the involved cells [1]. The method is not too invasive and allows for local and selective destruction of the involved tissues. An additional benefit is a positive cosmetic effect. The treatment is quite well tolerated, however, the most significant problem is pain with varied degrees dependent on the type of lesion, its site and size [7].

Due to high demand for effective treatment of AK, modern modification of the photodynamic method are being sought, including the ones that apply light-emitting diodes (LEDs). One of them is a device build with matrixes of superluminescent light-emitting diodes (sLEDs) that allows for obtaining optimal conditions to conduct the procedure [8].

\section{OBJECTIVE}

The aim of the study is to present original observations regarding the application of photodynamic therapy for AK. Studies evaluating efficacy and safety of photodynamic therapy with the use of superluminescent LED lamps were conducted thanks to scientific cooperation between the Department of Dermatology, Venereology and Paediatric Dermatology Medical University of Lublin and the Institute of Optoelectronics at the Jarosław Dąbrowski Military University of Technology in Warsaw.
Rozpoznanie AK najczęściej ustala się na podstawie wywiadu, oglądania i badania palpacyjnego zmian skórnych. W przypadkach wątpliwych i podejrzanych o rozwój postaci inwazyjnej największe znaczenie ma wynik badania histopatologicznego. Obecnie ważną rolę w diagnostyce odgrywa metoda dermatoskopowa. Zalaudek i wsp. [3] zaobserwowali, że występuje zależność między klinicznym stopniem nasilenia AK wg klasyfikacji Olsen i wsp. [4] a obrazem dermatoskopowym. Zmiany cienkie, w stopniu I, charakteryzuje czerwona pseudosiatka naczyniowa. W przypadku zmian klinicznie ocenianych jako stopień II w dermatoskopii można zaobserwować tak zwany wzór truskawki, natomiast w stopniu III - białożółte obszary bezstrukturalne [3].

Rogowacenie słoneczne jest przewlekłym schorzeniem skóry, niejednokrotnie wymagającym wielu cykli MAL leczenia, a wybór metody zależy od grubości i liczby ognisk chorobowych oraz ich rozległości [5]. Rozwój raka kolczystokomórkowego zależy od stopnia uszkodzenia posłonecznego oraz czasu jego trwania [1]. Szacuje się, że roczne ryzyko przemiany złośliwej pojedynczego ogniska AK wynosi 0,025-16\%. Jest ono znacznie wyższe $w$ przypadku występowania licznych zmian, zwłaszcza zajmujących rozległe powierzchnie skóry [6].

Terapia fotodynamiczna jest uznaną i skuteczną metodą postępowania, szczególnie u pacjentów ze zmianami powierzchownymi i średniej grubości. Mechanizm jej działania polega na zastosowaniu fotouczulacza, gromadzącego się w nieprawidłowych komórkach, który następnie jest aktywowany przez światło o odpowiedniej długości fali, co przyczynia się do tworzenia reaktywnych form tlenu, w tym tlenu singletowego. Prowadzi to do zmian w mikrokrążeniu, miejscowej reakcji zapalnej oraz śmierci zajętych komórek [1]. Metoda jest mało inwazyjna i umożliwia miejscowe i wybiórcze niszczenie zmienionej tkanki. Dodatkową jej zaletą jest dobry efekt kosmetyczny. Leczenie jest dość dobrze tolerowane, największy problem stanowi występujący podczas naświetlania ból o różnym nasileniu w zależności od rodzaju zmiany, jej umiejscowienia i rozmiaru [7].

W związku z dużym zapotrzebowaniem na skuteczne leczenie AK poszukuje się nowoczesnych modyfikacji metody fotodynamicznej, m.in. z wykorzystaniem światła typu LED (light emitting diodes). Jedną z nich jest urządzenie zbudowane z matryc diod superluminescencyjnych (sLED), które umożliwia uzyskanie optymalnych warunków do przeprowadzenia zabiegu [8].

\section{CEL PRACY}

Celem pracy jest przedstawienie własnych obserwacji dotyczących zastosowania terapii fotodynamicznej w AK. Badania oceniające skuteczność i bezpieczeństwo terapii fotodynamicznej z użyciem superluminescencyjnej lampy sLED zostały przeprowadzone dzięki reali- 
The paper presents three chosen cases of patients treated at the Department of Dermatology, Venereology and Paediatric Dermatology, Medical University of Lublin, by means of photodynamic methods including an sLED lamp and earlier application of aminolevulinic acid (ALA). A preparation containing $16 \%$ 5-aminolevulinic acid (ALA) cream, Hascobaza, was used. Purity of the applied ALA was checked with high-performance liquid chromatography (HPLC) and reached the level of $99.9 \%$.

Diagnostics of AK in the presented patients was performed by means of a dermatoscope and palpation. Thickness of foci was determined on the basis of the Olsen et al. [4] scale (grade 1 - thin/superficial lesions, poorly visible, palpable; grade 2 - medium-thick lesions, clearly visible and palpable; grade 3 - thick and hyperkeratotic lesions).

After debridement of scales and crusts from the affected skin area, the ALA cream was applied and covered with an occlusive dressing for 3 hours. Then, cream debris were removed with a gauze pad soaked with a $0.9 \%$ sodium chloride solution.

The procedure utilized a light source based on sLED matrixes produced by Medlight that allows for zacji wspólnego projektu naukowego Katedry i Kliniki Dermatologii, Wenerologii i Dermatologii Dziecięcej Uniwersytetu Medycznego w Lublinie i Instytutu Optoelektroniki Wojskowej Akademii Technicznej im. Jarosława Dąbrowskiego w Warszawie.

\section{MATERIAŁ I METODY}

Przedstawiamy trzy wybrane przypadki pacjentów leczonych w Klinice Dermatologii, Wenerologii i Dermatologii Dziecięcej Uniwersytetu Medycznego w Lublinie metodą fotodynamiczną przy użyciu lampy sLED po wcześniejszej aplikacji kwasu aminolewulinowego (ALA). Zastosowano preparat zawierający kwas 5-aminolewulinowy o stężeniu 16\% w podłożu maściowym Hascobaza. Czystość użytego ALA sprawdzana przy użyciu wysokosprawnej chromatografii cieczowej (high-performance liquid chromatography - HPLC) była na poziomie $99,9 \%$.

Diagnostykę AK u przedstawionych chorych przeprowadzano przy użyciu dermatoskopu oraz badania palpacyjnego. Grubość ognisk określano na podstawie klasyfikacji Olsen i wsp. [4] (stopień I - zmiany cienkie lub powierzchowne, słabo widoczne, wyczuwalne palpacyjnie; stopień II - zmiany średniej grubości, dobrze
A

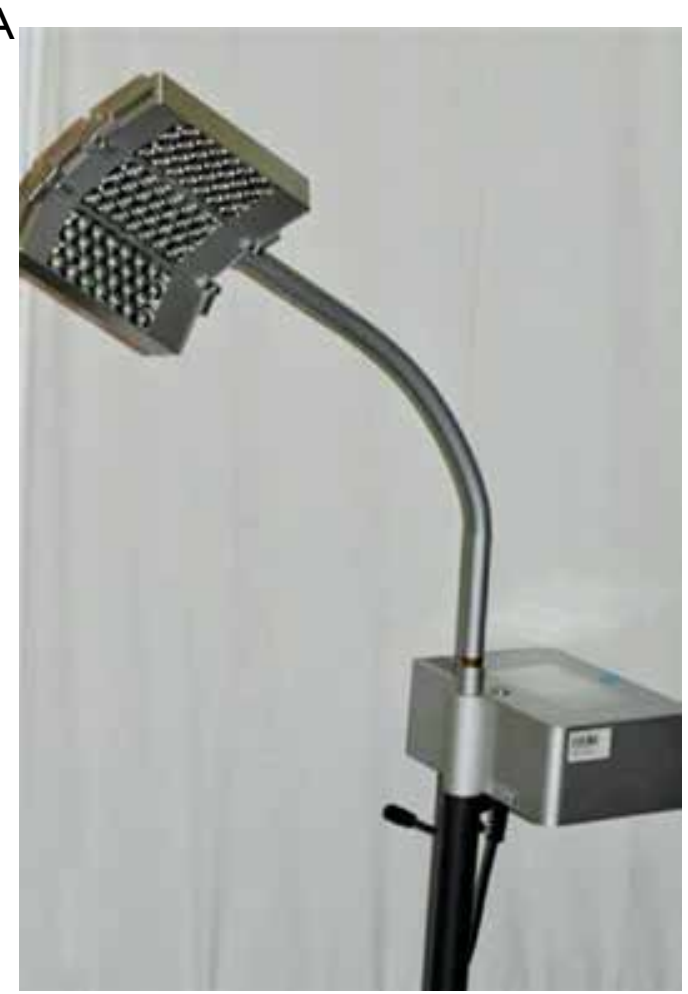

B

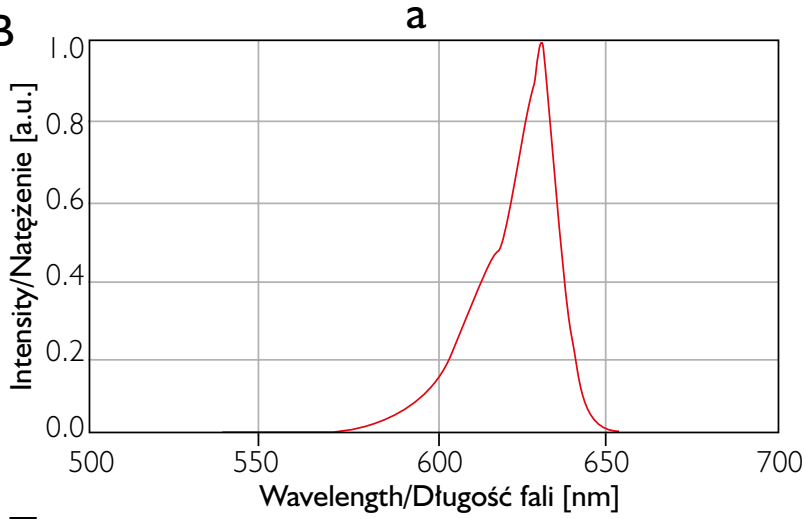

b

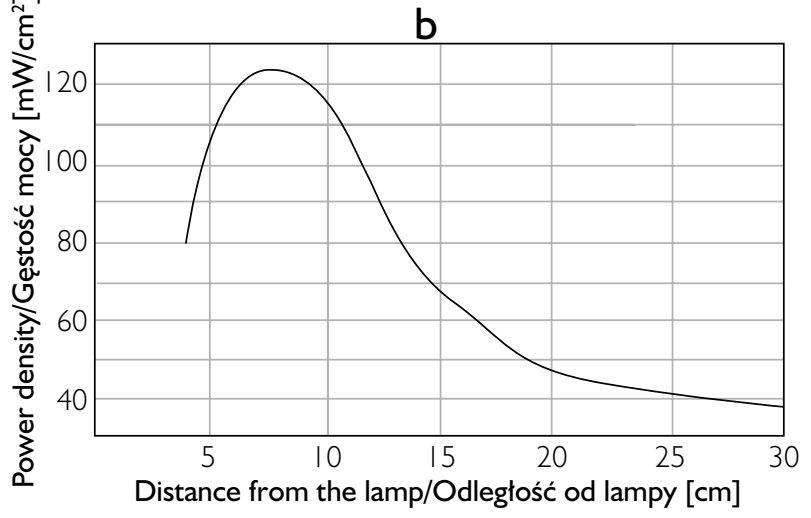

Figure I. sLED matrix source (A) as well as spectral (a) and energetic (b) characteristics of APRO light source (B)

Rycina I. Źródło światła typu matryca sLED (A) oraz charakterystyka widmowa (a) i energetyczna (b) źródła światła APRO (B) 
pulsed mode of work (fig. 1). Length of the emitted irradiation wave was $630 \pm 5 \mathrm{~nm}$, and the exposure time was 13 minutes and 47 seconds. Duration of a single impulse - $430 \mathrm{~ms}$, and the interval between impulses - $130 \mathrm{~ms}$.

Power density $\left[\mathrm{mW} / \mathrm{cm}^{2}\right]$ depending on the distance between the lamp and skin surface was determined on the basis of a graph (fig. 1). Dose of light, i.e. the amount of energy $\left[\mathrm{J} / \mathrm{cm}^{2}\right]$, was calculated by using the following formula: $D=P\left[\mathrm{~mW} / \mathrm{cm}^{2}\right] \times t[\mathrm{~s}]$, where: $D$ - dose of light, $P$ - power density, $t$ - time.

Initial distance between the lamp and exposed skin area was $5-8 \mathrm{~cm}$ and was increased when a patient reported discomfort, such as a burning sensation and/or pain.

Clinical assessment was conducted during and directly after the procedure, as well as during follow-up visits after a week and 3 months. Severity of subjective discomfort such as pain and burning sensation was determined with a ten-point visual analogue scale (VAS). Erythema, scales and crusts were classified as mild, moderately severe and severe, depending on their severity.

The study project was given a positive opinion of the Bioethics Committee at the Medical University of Lublin (KE-0254/173/2016).

\section{RESULTS}

\section{Patient I}

A 75-year-old man, skin phototype 2, with extensive foci of AK on the top of his head, frontotemporal region and nose that have been present for about 20 years. The patient reported frequent exposure to sun during the summertime and numerous sunburn episodes.

Physical examination confirmed keratotic foci grade 1 and 2; in the region of the left eyebrow ridge grade 3 according to the Olsen classification.

For a couple of years, the patient was undergoing cryosurgical procedures involving liquid nitrogen that failed to bring satisfactory results. Due to the AK extent, the patient underwent several photodynamic procedures with the sLED lamp that regarded the affected skin areas.

During the procedure the patient denied feeling pain, however, he reported a burning sensation estimated at 7 on the VAS. Therefore, it was necessary to make breaks in irradiation and increase the distance between the lamp and the skin surface from $8 \mathrm{~cm}$ (power density: $123 \mathrm{~mW} / \mathrm{cm}^{2}$; dose of light $\sim 100 \mathrm{~J} / \mathrm{cm}^{2}$ ) to maximum $30 \mathrm{~cm}$ (power density: $39 \mathrm{~mW} / \mathrm{cm}^{2}$; dose of light $\sim 32 \mathrm{~J} / \mathrm{cm}^{2}$ ).

A mild erythema was observed directly after the procedure. During a follow-up visit a week after widoczne i wyczuwalne palpacyjnie; stopień III - zmiany grube, hiperkeratotyczne).

Po odwarstwieniu łusek i strupów z powierzchni zmienionej chorobowo skóry nakładano krem z ALA pod opatrunek okluzyjny na 3 godziny. Następnie resztki kremu usuwano gazikiem nasączonym 0,9-procentowym roztworem chlorku sodu.

Do naświetlania użyto źródła światła opartego na matrycach sLED firmy Medlight umożliwiających pulsacyjny tryb pracy (ryc. 1). Długość emitowanej fali promieniowania urządzenia wynosiła $630 \pm 5 \mathrm{~nm}$, a czas naświetlania 13 minut i 47 sekund. Czas trwania pojedynczego impulsu wynosił 430 ms, a przerwa między impulsami $130 \mathrm{~ms}$.

Gęstość mocy $\left[\mathrm{mW} / \mathrm{cm}^{2}\right]$ w zależności od odległości lampy od powierzchni skóry wyznaczono na podstawie wykresu (ryc. 1). Dawkę światła, czyli ilość dostarczonej energii $\left[\mathrm{J} / \mathrm{cm}^{2}\right]$, obliczono na podstawie wzoru: $D=$ $P\left[\mathrm{~mW} / \mathrm{cm}^{2}\right] \times t[\mathrm{~s}]$, gdzie $D$ to dawka światła, $P$ - gęstość mocy, a $t$-czas.

Wstępna odległość lampy od naświetlanego obszaru skóry wynosiła 5-8 cm. Zwiększano ją w przypadku zgłaszania przez pacjenta dolegliwości subiektywnych, takich jak pieczenie i/lub ból.

Ocenę kliniczną przeprowadzano w trakcie naświetlania i bezpośrednio po naświetlaniu oraz podczas wizyt kontrolnych po tygodniu i po 3 miesiącach. Nasilenie dolegliwości subiektywnych, takich jak ból i pieczenie, określano przy użyciu 10-punktowej skali VAS (visual analogue scale). Rumień, złuszczanie i strupki, w zależności od ciężkości, klasyfikowano jako łagodne, średnio ciężkie i ciężkie.

Projekt badania uzyskał pozytywną opinię Komisji Bioetycznej przy Uniwersytecie Medycznym w Lublinie (KE-0254/173/2016).

\section{WYNIKI}

\section{Pacjent I}

Mężczyzna 75-letni, fototyp skóry II, z występującymi od około 20 lat rozległymi ogniskami AK na szczycie głowy, okolicach czołowo-skroniowych, nosie. Pacjent podawał w wywiadzie częste ekspozycje na słońce w okresie letnim z licznymi epizodami oparzeń.

W badaniu fizykalnym stwierdzono ogniska rogowacenia w stopniu I i II, w okolicy lewego łuku brwiowego w stopniu III wg klasyfikacji Olsen.

U pacjenta przez kilka lat stosowano zabiegi kriochirurgiczne z użyciem ciekłego azotu, które nie przyniosły zadowalającego efektu. Ze względu na rozległość AK u pacjenta wykonano kilka zabiegów terapii fotodynamicznej z użyciem lampy sLED na poszczególne zmienione obszary skóry.

W trakcie zabiegu pacjent negował ból, natomiast zgłaszał odczucie pieczenia o nasileniu 7 w skali VAS. 

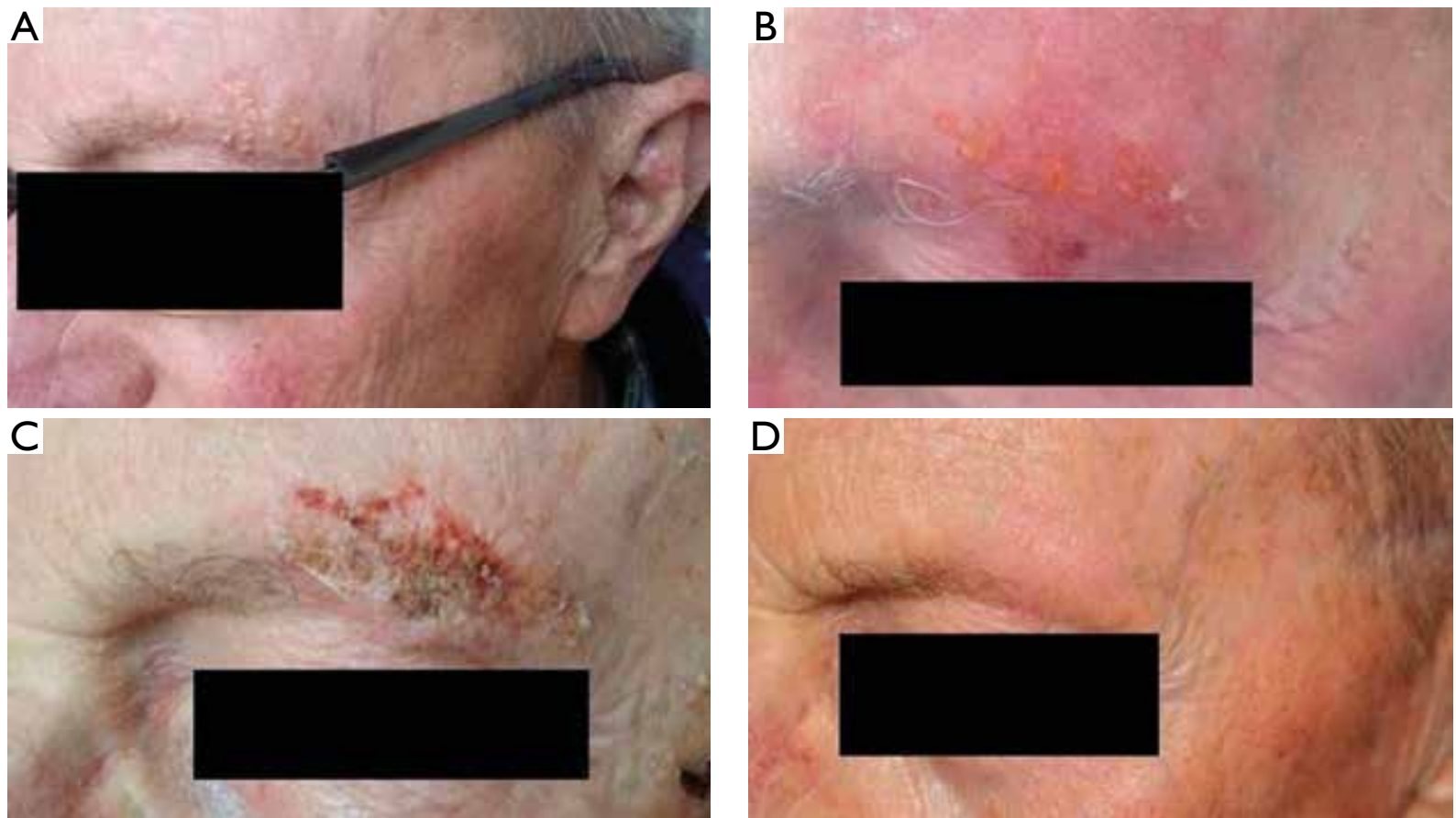

Figure 2. Patient I before the procedure with the use of superluminescent LED lamp (A), just after the procedure (B), I week after the procedure (C) and 3 months after the procedure (D)

Rycina 2. Pacjent I przed zabiegiem z użyciem superluminescencyjnej lampy sLED (A), bezpośrednio po zabiegu (B), tydzień po zabiegu (C) oraz 3 miesiące po zabiegu (D)

the procedure, small scales and thick haemorrhagic crusts were confirmed. The lesions regarded the entire area involved in the therapy (keratotic foci and surrounding skin). It was necessary to repeat the procedure on the left eyebrow ridge 3 weeks after the procedure. After 3 months since the procedure, no recurrent $\mathrm{AK}$ foci were observed in the area covered by the procedure (fig. 2).

\section{Patient 2}

A 54-year-old man, skin phototype 2, with extensive foci of AK on the top of his head, and frontotemporal region that have been present for about 10 years. Physical examination revealed keratotic foci grade 1 and 2 according to the Olsen scale. Due to the extent of skin lesions, the procedure was divided into several stages. The distance between the lamp and skin surface was $8 \mathrm{~cm}$ (power density: $123 \mathrm{~mW} / \mathrm{cm}^{2}$; dose of light $\sim 100 \mathrm{~J} / \mathrm{cm}^{2}$ ).

During the procedure, the patient reported a strong burning sensation that he estimated at 9 on the VAS, and pain with the intensity of 5 points. Directly after the procedure, severe erythema with slight oedema and punctate oozing of serous secretion was observed.

During a follow-up severe visit after a week since the procedure, moderate scales and thick, sometimes haemorrhagic, crusts were confirmed. After 3 months, AK recurrence was not observed (fig. 3).
W związku z tym konieczne były przerwy w naświetlaniu i zwiększenie odległości lampy od powierzchni skóry z $8 \mathrm{~cm}$ (gęstość mocy $123 \mathrm{~mW} / \mathrm{cm}^{2}$, ilość dostarczonej energii $\sim 100 \mathrm{~J} / \mathrm{cm}^{2}$ ) do maksymalnie $30 \mathrm{~cm}$ (gęstość mocy $39 \mathrm{~mW} / \mathrm{cm}^{2}$, ilość dostarczonej energii $\left.\sim 32 \mathrm{~J} / \mathrm{cm}^{2}\right)$.

Bezpośrednio po zabiegu obserwowano rumień o średnim nasileniu. Podczas wizyty kontrolnej po tygodniu od naświetlania stwierdzono niewielkie złuszczanie oraz grube, krwotoczne strupki. Zmiany dotyczyły całego obszaru objętego terapią (ogniska rogowacenia i skóra wokół). W obrębie lewego łuku brwiowego konieczne było powtórzenie zabiegu po 3 tygodniach. Po 3 miesiącach od naświetlania w miejscu poddanym zabiegowi nie obserwowano nawrotu ognisk AK (ryc. 2).

\section{Pacjent 2}

Mężczyzna 54-letni, fototyp skóry II, z występującymi od około 10 lat rozległymi ogniskami AK na szczycie głowy oraz okolicach czołowo-skroniowych. W badaniu fizykalnym stwierdzono ogniska rogowacenia w stopniu I i II wg Olsen. Ze względu na rozległość zmian skórnych zabieg podzielono na kilka etapów. Odległość lampy od naświetlanej powierzchni skóry wynosiła $8 \mathrm{~cm}$ (gęstość mocy $123 \mathrm{~mW} / \mathrm{cm}^{2}$, ilość dostarczonej energii $\left.\sim 100 \mathrm{~J} / \mathrm{cm}^{2}\right)$.

W trakcie naświetlania pacjent zgłaszał silne uczucie pieczenia, które w skali VAS określił na 9, oraz ból o nasileniu 5 pkt. Bezpośrednio po zabiegu obserwowa- 

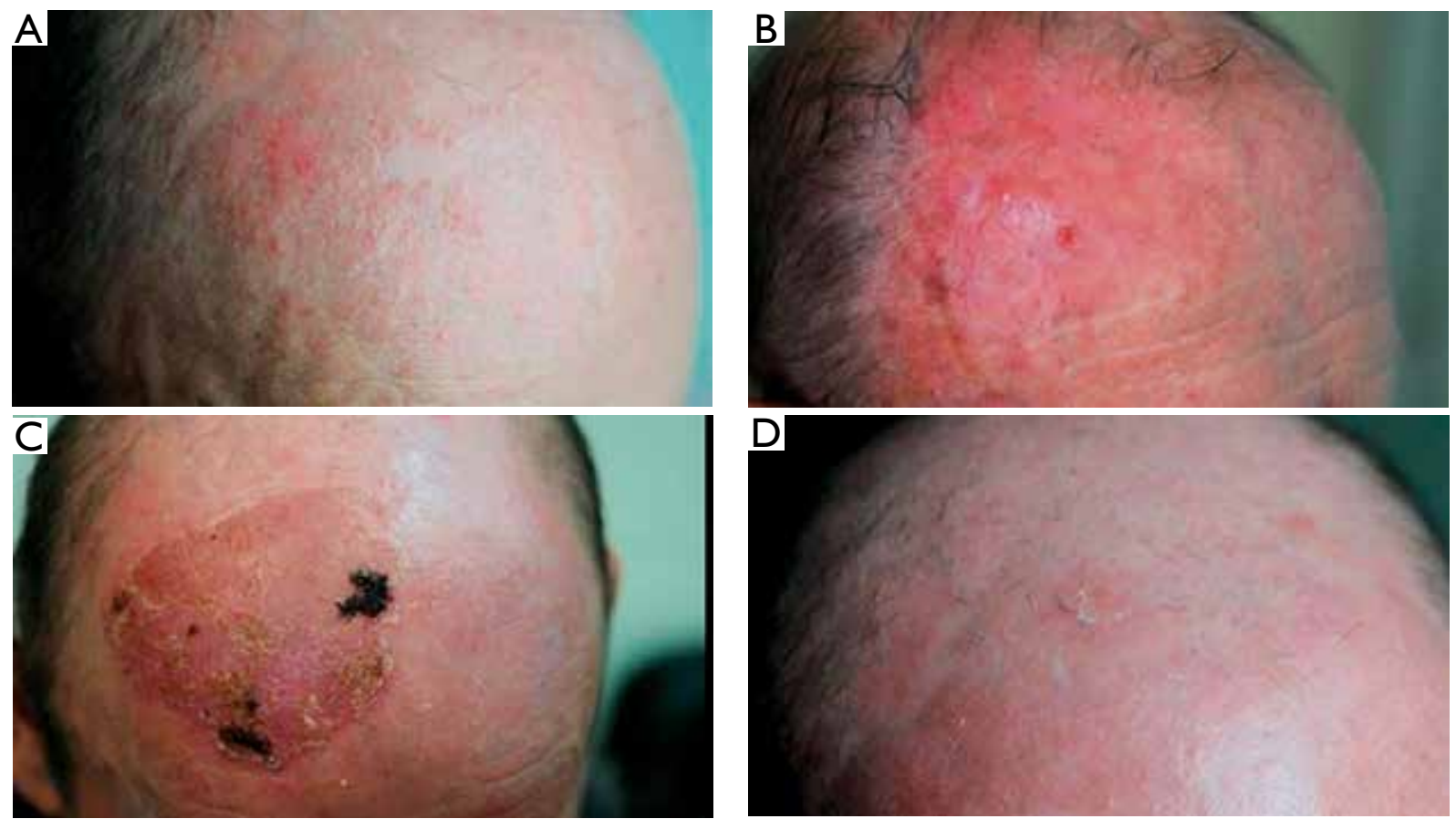

Figure 3. Patient 2 before the procedure with the use of superluminescent LED lamp (A), just after the procedure (B), I week after the procedure (C) and 3 months after the procedure (D)

Rycina 3. Pacjent 2 przed zabiegiem z użyciem superluminescencyjnej lampy sLED (A), bezpośrednio po zabiegu (B), tydzień po zabiegu (C) oraz 3 miesiące po zabiegu (D)

\section{Patient 3}

A 77-year-old woman, skin phototype 2, with spread $\mathrm{AK}$ foci on the cheeks and frontotemporal region that have been present for over 20 years. Physical examination revealed a dozen of clearly defined AK foci covered in scales. The surrounding skin was unaffected, what was confirmed upon palpation and dermoscopy that did not show signs of AK.

A cream with $16 \%$ of ALA was applied to particular foci and surrounding $5 \mathrm{~mm}$ area of healthy skin; then, the area was covered with an occlusive dressing. The distance between the lamp and skin surface was $8 \mathrm{~cm}$ (power density: $123 \mathrm{~mW} / \mathrm{cm}^{2}$; dose of light $\sim 100 \mathrm{~J} / \mathrm{cm}^{2}$ ).

During the procedure, the patient denied experiencing pain; however, she reported a burning sensation with estimated intensity at 2 on the VAS. Directly after the procedure, mild skin erythema was observed.

During a follow-up visit a week since the procedure, slight scales and small crusts were confirmed. After 6 months, recurrence of AK foci was not observed at the area that was involved in the procedure (fig. 4).

\section{DISCUSSION}

Efficacy of AK treatment involving photodynamic therapy reaches $75-92 \%$ [9]. In this method, lesions covering the face respond to treatment better than the no rumień o dużym nasileniu z niewielkim obrzękiem i punkcikowatym sączeniem wydzieliny surowiczej.

W trakcie wizyty kontrolnej po tygodniu od naświetlania stwierdzono umiarkowane złuszczanie oraz grube, miejscami krwotoczne strupki. Po 3 miesiącach nie obserwowano nawrotu AK (ryc. 3).

\section{Pacjent 3}

Kobieta 77-letnia, fototyp skóry II, z występującymi od ponad 20 lat licznymi, rozsianymi ogniskami AK na policzkach oraz okolicach czołowo-skroniowych. W badaniu fizykalnym stwierdzono kilkanaście wyraźnie odgraniczonych ognisk AK pokrytych łuskami. Skóra wokół była niezmieniona, co potwierdzono w badaniach palpacyjnym i dermatoskopowym, w których nie wykazano cech AK.

Krem z ALA w stężeniu 16\% nakładano na poszczególne ogniska oraz otaczający 5-milimetrowy obszar zdrowej skóry i przykrywano opatrunkiem okluzyjnym. Odległość lampy od naświetlanej powierzchni skóry wynosiła $8 \mathrm{~cm}$ (gęstość mocy $123 \mathrm{~mW} / \mathrm{cm}^{2}$, ilość dostarczonej energii $\sim 100 \mathrm{~J} / \mathrm{cm}^{2}$ ).

$\mathrm{W}$ trakcie naświetlania pacjentka negowała ból, natomiast zgłaszała uczucie pieczenia o nasileniu 2 w skali VAS. Bezpośrednio po zabiegu obserwowano rumień o charakterze łagodnym.

Podczas wizyty kontrolnej po tygodniu od naświetlania stwierdzono niewielkie złuszczanie oraz strup- 

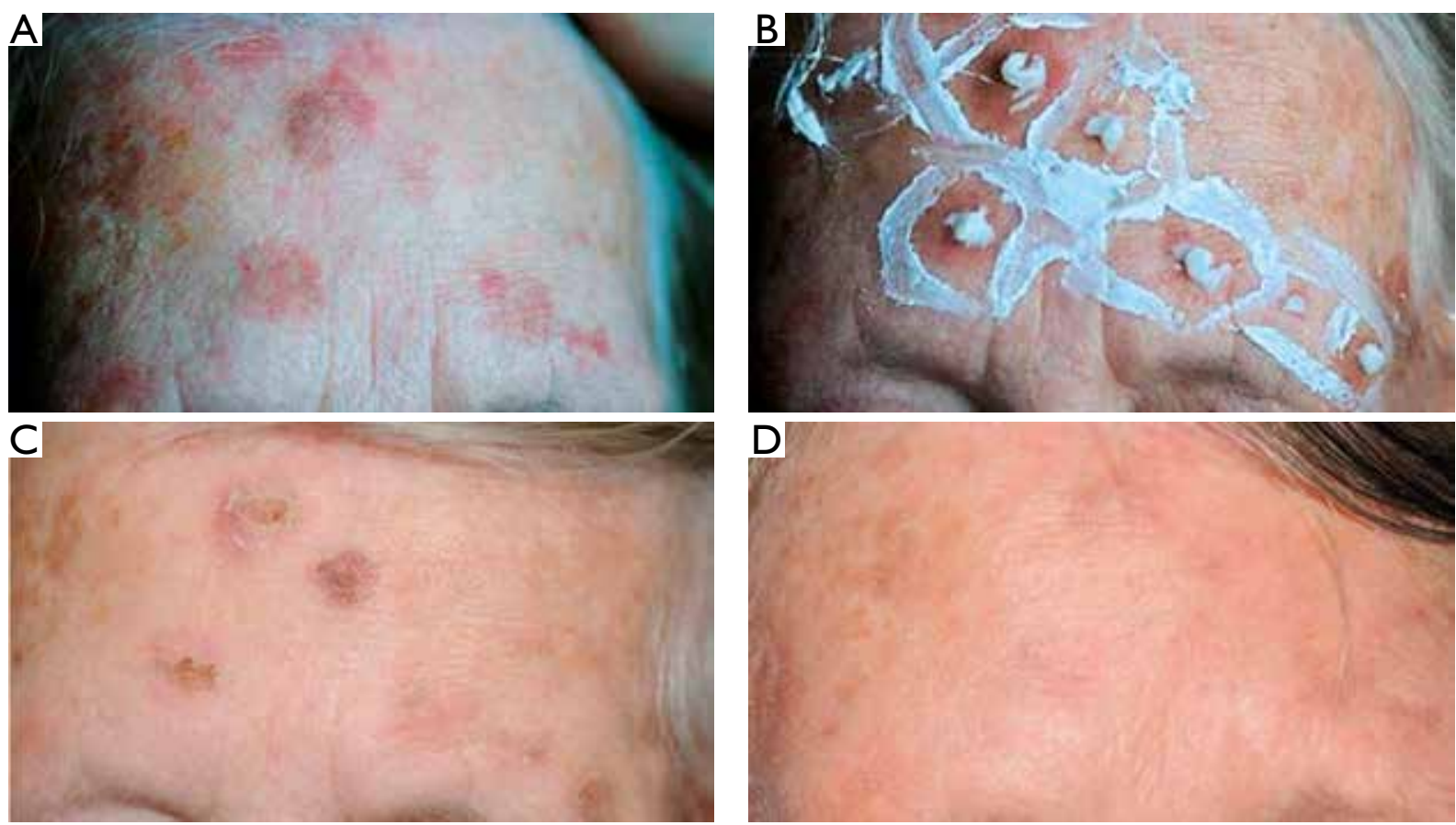

Figure 4. Patient 3 before the procedure with the use of superluminescent LED lamp (A), after application of a cream with I6\% 5-aminolevulinic acid (ALA) to particular areas of actinic keratosis on the forehead (B), I week after the procedure (C) and 3 months after the procedure (D)

Rycina 4. Pacjent 3 przed zabiegiem z użyciem superluminescencyjnej lampy sLED (A), po nałożeniu kremu z kwasem 5-aminolewulinowym w stężeniu 16\% na poszczególne ogniska rogowacenia słonecznego na czole (B), tydzień po zabiegu (C) oraz 3 miesiące po zabiegu (D)

ones of other skin regions [10]. Red light is most commonly used thanks to its good penetration into the tissue [9]. Photodynamic therapy with ALA is ranked high among AK treatment methods thanks to its efficacy and beneficial safety profile [11].

In the presented patients, we used a modern sLED matrix illuminator with a head consisting in three mobile parts that could be adjusted to the skin area during irradiation. Additional advantages of the device include a so-called "soft start" meaning that during the first 4 minutes of irradiation the power increases from $40 \%$ to $100 \%$, while protecting the earlier administered photosensitizer from a too fast decomposition, and a pulsation mode that ensures maintenance of a proper level of oxygenated haemoglobin used during the procedure [8].

Our original studies regarding efficacy and safety of photodynamic therapies with the use of sLED lamps in AK published in 2018 [12] showed a complete disappearance of disease's symptoms after 3 months since the procedure in $81.82 \%$ of patients with lesions grade 1 and 2 according to the Olsen scale.

Similarly to our observations, Radakovic et al. [13] confirmed that 3 months after an individual procedure, AK foci disappeared in 69-81\%. Then, Buinauskaite et al. [14] conducted two procedures with a 2-week interval for patients with lesions on the head ki. Po 3 miesiącach $\mathrm{w}$ miejscu poddanym zabiegowi nie obserwowano nawrotu ognisk AK (ryc. 4).

\section{OMÓWIENIE}

Skuteczność leczenia AK przy użyciu terapii fotodynamicznej wynosi 75-92\% [9]. Tej metodzie lepiej poddają się zmiany zajmujące twarz w porównaniu z innymi okolicami skóry [10]. Najczęściej wykorzystywane jest światło czerwone w związku z jego dobrym przenikaniem w głąb tkanki [9]. Ze względu na skuteczność i korzystny profil bezpieczeństwa terapia fotodynamiczna z użyciem ALA zajmuje wysoką pozycję wśród metod leczenia AK [11].

U przedstawionych pacjentów zastosowano nowoczesne matrycowe źródło światła sLED z głowicą zbudowaną z trzech ruchomych części umożliwiających dopasowanie do powierzchni naświetlanej skóry. Dodatkowymi zaletami tego urządzenia są tzw. miękki start, który oznacza, że w trakcie pierwszych 4 minut naświetlania moc wzrasta od $40 \%$ do $100 \%$ maksymalnej wartości, co chroni przed zbyt szybkim rozkładem wcześniej podanego fotouczulacza, a także tryb pulsacyjny, zapewniający utrzymywanie właściwego stężenia oksyhemoglobiny zużywanej podczas zabiegu [8]. 
and face skin, and achieved remission of symptoms in $92.1-100 \%$ of the cases after 3 months, and in 84.2$92.1 \%$ of cases after 6 months. Finally, Serra-Guillén et al. [15] did not note significant differences in the procedure efficacy with regard to a photosensitizer used (preparations with aminolevulinic acid in nanoemulsion - BP200-ALA, or methyl aminolevulinate ester - MAL). AK recurrence assessed after 12 months by Ko et al. [16] was $15.4 \%$ after application of ALA cream, and $20.9 \%$ after the use of a preparation with MAL.

There exist a number of modifications of the photodynamic therapy, whose aim is to obtain the best therapeutic effects with the possibly the smallest side effects. Some authors claim that repetition of the procedure every 2 weeks decreases the risk for disease recurrence [9]. Performing an individual procedure may not suffice in case of thick lesions (grade 3, and sometimes 2 according to the Olsen scale), what we observed in the presented patient case (case 1) with regard to his eyebrow arch. In addition, with such a location, no cicatrisation is an unquestionable benefit of the photodynamic therapy since there is no hair follicle damage. The patients (cases 2 and 3 ) that had AK foci grade 1 and 2 did not require another cycle of irradiation.

Regular monitoring of patients, especially the ones from the risk group that includes older men with skin phototype 1 and 2, allows for early diagnosis and disease treatment [6].

In the presented patient (case 1), an implementation of the photodynamic field-directed therapy with the use of sLED lamp led to subsiding of the lesions without their recurrence after 3 months since the procedure.

Observed extensive AK lesions in the presented patient (case 2) subsided after one cycle of treatment with the sLED lamp, without a recurrence after 3 months. It allowed for avoiding other less effective procedures that could require multiple repeats.

The female patient (case 3) required a spot application of ALA cream (lesion-directed therapy) before the photodynamic therapy with the sLED lamp due to the presence of clearly demarcated AK foci grade 2 and no palpable lesions within the surrounding skin. During irradiation, the patient reported only a slight burning sensation estimated at 2 on the VAS. During 3 months after the procedure no lesion recurrence was observed. sLED lamp treatment may also be an effective alternative in cases of single AK foci.

Photodynamic therapy is a safe and well-tolerated treatment method, and occurring adverse reactions are usually harmless and transient. They include erythema, oedema, pain, and burning sensation. Furthermore, the following may appear: discolouration, hyperpigmentation, milia, and exacerbation of rosa-
W badaniach własnych dotyczących skuteczności i bezpieczeństwa terapii fotodynamicznej z użyciem lampy sLED w AK, opublikowanych w 2018 roku [12], stwierdzono całkowite ustąpienie objawów chorobowych po 3 miesiącach od zabiegu u 81,82\% pacjentów ze zmianami w stopniu I i II wg Olsen.

Podobnie jak w naszych obserwacjach Radakovic i wsp. [13] stwierdzili, że 3 miesiące po jednorazowym zabiegu ogniska AK ustąpiły w 69-81\% przypadków. Buinauskaite i wsp. [14] przeprowadzili u pacjentów ze zmianami na skórze głowy i twarzy dwa zabiegi w odstępie 2-tygodniowym. Po 3 miesiącach uzyskali ustąpienie objawów u 92,1-100\% badanych, a po 6 miesiącach u 84,2-92,1\% badanych. Serra-Guillén i wsp. [15] nie stwierdzili istotnych różnic w skuteczności zabiegu niezależnie od zastosowanego fotouczulacza (preparat $\mathrm{z}$ kwasem aminolewulinowym w nanoemulsji - BP200-ALA lub ester metylowego kwasu aminolewulinowego, methyl aminolevulinate - MAL). Odsetek nawrotów AK oceniony po 12 miesiącach przez Ko i wsp. [16] wynosił 15,4\% po zastosowaniu kremu z ALA oraz 20,9\% przy użyciu preparatu z MAL.

Istnieje wiele modyfikacji terapii fotodynamicznej, których celem jest uzyskanie jak najlepszego efektu leczniczego przy możliwie najmniejszych działaniach niepożądanych. Niektórzy autorzy uważają, że powtarzanie zabiegów co 2 tygodnie zmniejsza ryzyko nawrotu choroby [9]. Przeprowadzenie pojedynczego zabiegu może być niewystarczające w przypadku zmian o większej grubości (stopień III, a niekiedy II wg Olsen), co również obserwowano u przedstawionego pacjenta (przypadek 1) w okolicy łuku brwiowego. Przy takiej lokalizacji niewątpliwą zaletą terapii fotodynamicznej jest brak bliznowacenia, ponieważ nie dochodzi do uszkodzenia mieszków włosowych. Pacjenci, u których występowały ogniska AK w stopniu I i II (przypadki 2 i 3), nie wymagali kolejnego cyklu naświetlania.

Systematyczne monitorowanie pacjentów, zwłaszcza z grupy ryzyka, do której należą starsi mężczyźni z I i II fototypem skóry, umożliwia wcześniejsze rozpoznanie i leczenie choroby [6].

U prezentowanego pacjenta (przypadek 1) zastosowanie terapii fotodynamicznej lampą sLED na cały obszar zagrożenia nowotworowego (field-directed therapy) spowodowało ustąpienie zmian chorobowych, bez nawrotu po 3 miesiącach od zabiegu.

Rozległe zmiany w postaci AK obserwowane u przedstawionego pacjenta (przypadek 2) ustąpiły po jednym cyklu naświetlania lampą sLED, bez nawrotu po 3 miesiącach. Pozwoliło to na uniknięcie innych, mniej skutecznych zabiegów, które wymagałyby wielokrotnych powtórzeń.

U pacjentki (przypadek 3), ze względu na obecność wyraźnie odgraniczonych ognisk AK w stopniu II 
cea [14]. Pain is an adverse symptom that limits the use of the photodynamic therapy in AK, especially in case of lesions found on the head. Subjective feelings reported by patients during irradiation are of different character and intensity, and are most commonly described as burning, stinging, and prickling. Occurrence of such side effects results from irritation of group C non-myelinated fibres, what is connected with the use of deep-penetrating red light $[7,9]$. Currently, daylight photodynamic therapies are tested to minimize adverse reactions. The method has its limitations as it may be conducted only during proper weather conditions [17].

On the basis of our earlier studies we concluded that tolerance of the procedure utilizing sLED lamps depends on the number and extent of AK foci, and the burning sensation is the most common adverse symptom [12].

Due to extensive sun damage areas on the head, during the procedures the presented patients (cases 1 and 2) reported burning sensation, which they estimated on the VAS as 7 and 9 points respectively. One of them (case 1) needed breaks during procedures, and it was necessary to increase the distance between the lamp and the skin surface from 8 to $30 \mathrm{~cm}$.

Some researchers think that pain depends on the photosensitizer used and is stronger with ALA as compared with MAL ester [18]. Then, Yazdanyar et al. [19] showed that pain intensity was not significantly different with MAL and ALA, and increased from the beginning of irradiation reaching its maximum after 5 minutes, and then, was gradually decreasing till it subsided completely at the end of the procedure.

It was possible to perform full treatment cycles in case of three presented patients despite reported pain, mostly in the form of a burning sensation. Applied breaks and increasing the distance between the lamp and the skin surface did not affect the efficacy of the therapy.

\section{CONCLUSIONS}

Diverse clinical picture of AK suggests an individual choice of the treatment method. Photodynamic therapy depends on the extent and nature of the skin lesions, as well as procedure tolerance by the patient. Photodynamic therapy allows for customizing the treatment with regard to an entire selected skin area (field-directed therapy), or individual lesions (lesion-directed therapy).

\section{CONFLICT OF INTEREST}

The authors declare no conflict of interest. i brak wyczuwalnych palpacyjnie zmian w obrębie przylegającej skóry, zastosowano terapię fotodynamiczną lampą sLED po wcześniejszym punktowym nałożeniu kremu z ALA (lesion-directed therapy). $W$ trakcie naświetlania pacjentka zgłaszała jedynie łagodne pieczenie o nasileniu $2 \mathrm{w}$ skali VAS. W czasie 3 miesięcy po zabiegu nie zaobserwowano nawrotu zmian. Leczenie lampą sLED może być również skuteczną metodą w przypadku pojedynczych ognisk AK.

Terapia fotodynamiczna jest bezpieczną i dość dobrze tolerowaną metodą leczenia, a występujące objawy niepożądane są najczęściej niegroźne i przejściowe. Należą do nich rumień, obrzęk, bolesność, pieczenie. Mogą ponadto wystąpić odbarwienia, przebarwienia, prosaki i zaostrzenie trądziku różowatego [14]. Ból jest objawem niepożądanym ograniczającym zastosowanie terapii fotodynamicznej w AK, zwłaszcza w przypadku zmian na skórze głowy. Odczucia subiektywne zgłaszane przez pacjentów w trakcie naświetlania mają różny charakter oraz nasilenie i najczęściej są określane jako pieczenie, palenie, kłucie. Wystąpienie tych objawów ubocznych wynika z podrażnienia bezmielinowych włókien $C$, co ma związek ze stosowaniem głęboko penetrującego światła czerwonego [7, 9]. Obecnie w celu zminimalizowania działań niepożądanych podejmowane są próby prowadzenia terapii fotodynamicznej z wykorzystaniem światła słonecznego (daylight photodynamic therapy). Ograniczeniem metody jest możliwość przeprowadzenia zabiegu jedynie $\mathrm{w}$ odpowiednich warunkach pogodowych [17].

Na podstawie wcześniejszych badań własnych stwierdzono, że tolerancja zabiegu z użyciem lampy sLED zależy od liczby i rozległości ognisk AK, a najczęstszym objawem niepożądanym jest pieczenie [12].

W związku z rozległym obszarem uszkodzenia słonecznego skóry głowy przedstawieni pacjenci (przypadki 1 i 2) w trakcie naświetlania zgłaszali dolegliwości w postaci pieczenia, które w skali VAS ocenili odpowiednio na 7 i 9 pkt. U jednego $\mathrm{z}$ nich (przypadek 1) konieczne były przerwy w naświetlaniu i zwiększenie odległości lampy od powierzchni skóry z $8 \mathrm{~cm}$ do $30 \mathrm{~cm}$.

Niektórzy badacze uważają, że odczucie bólu zależy od użytego fotouczulacza i jest większe przy zastosowaniu ALA w porównaniu z estrem MAL [18]. Yazdanyar i wsp. [19] stwierdzili, że intensywność bólu nie różniła się istotnie przy zastosowaniu MAL i ALA i narastała od rozpoczęcia naświetlania, uzyskując maksimum po 5 minutach, a następnie zmniejszała się, ustępując całkowicie wraz z zakończeniem terapii.

U 3 prezentowanych pacjentów pomimo zgłaszanych dolegliwości (głównie w postaci pieczenia) możliwe było przeprowadzenie pełnych cykli leczenia. Przerwy w naświetlaniu i zwiększanie odległości 
lampy od powierzchni skóry nie miały wpływu na skuteczność terapii.

\section{WNIOSKI}

Zróżnicowany obraz kliniczny AK skłania do indywidualnego doboru sposobu leczenia. Przeprowadzenie terapii fotodynamicznej zależy od rozległości i charakteru zmian skórnych oraz tolerancji zabiegu przez pacjenta. Terapia fotodynamiczna umożliwia indywidualne przeprowadzenie zabiegu, $\mathrm{z}$ uwzględnieniem całego wybranego obszaru skóry (field-directed therapy) lub poszczególnych zmian chorobowych (lesion-directed therapy).

\section{KONFLIKT INTERESÓW}

Autorzy nie zgłaszają konfliktu interesów.

\section{References}

\section{Piśmiennictwo}

1. de Oliveira E.C.V., da Motta V.R.V., Pantoja P.C., Ilha C.S.O., Magalhães R.F., Galadari H., et al.: Actinic keratosis - review for clinical practice. Int J Dermatol 2019, 58, 400-407.

2. Kopera D., Kerl H.: Visualization and treatment of subclinical actinic keratoses with topical imiquimod $5 \%$ cream: an observational study. Biomed Res Int 2014, 2014, 135916.

3. Zalaudek I., Piana S., Moscarella E., Longo C., Zendri E., Castagnetti F., et al.: Morphologic grading and treatment of facial actinic keratosis. Clin Dermatol 2014, 32, 80-87.

4. Olsen E.A., Abernethy M.L., Kulp-Shorten C., Callen J.P., Glazer S.D., Huntley A., et al.: A double-blind, vehicle-controlled study evaluating masoprocol cream in the treatment of actinic keratoses on the head and neck. J Am Acad Dermatol 1991, 24, 738-743.

5. Lacour J.P., Ulrich C., Gilaberte Y., Von Felbert V., Basset-Seguin N., Dreno B., et al.: Daylight photodynamic therapy with methyl aminolevulinate cream is effective and nearly painless in treating actinic keratoses: a randomised, investigator-blinded, controlled, phase III study throughout Europe. J Eur Acad Dermatol Venereol 2015, 29, 2342-2348.

6. Schmitz L., Hessam S., Scholl L., Reitenbach S., Segert M.H., Gambichler T., et al.: Argon plasma coagulation of actinic keratoses imaged by optical coherence tomography: an in vivo study indicating a possible lesion-directed treatment. J Biophotonics 2018, 11, e201800075.

7. Nawrocka-Musiał D., Nawrocka E., Latocha M.: Ból jako efekt uboczny terapii fotodynamicznej i metody jego leczenia. Acta Bio-Opt Inform Med Inż Biomed 2017, 23, 57-68.

8. Kwaśny M., Mierczyk Z.: Współczesne źródła światła dla metody PDT. Terapia Fotodynamiczna 2015, 1, 10-26.

9. Osiecka B.J., Nockowski P., Szepietowski J.C.: Treatment of actinic keratosis with photodynamic therapy using red or green light: a comparative study. Acta Derm Venereol 2018, 98, 689-693.

10. Morton C.A., Wulf H.C., Szeimies R.M., Gilaberte Y., Basset-Seguin N., Sotiriou E., Piaserico S., et al.: Practical approach to the use of daylight photodynamic therapy with topical methyl aminolevulinate for actinic keratosis: a European consensus. J Eur Acad Dermatol Venereol 2015, 29, 1718-1723.

11. Vegter S., Tolley K.: A network meta-analysis of the relative efficacy of treatments for actinic keratosis of the face or scalp in Europe. PLoS One 2014, 9, e96829.

12. Bartosińska J., Wolska-Gawron K., Gerkowicz A., Niewiedzioł M., Michalska-Jakubus M., Komza M., et al.: Photodynamic therapy with the use of superluminescent diodes (sLED) in the treatment of actinic keratosis. Photodiagnosis Photodyn Ther 2018, 22, 187-190.

13. Radakovic S., Tanew A.: 5-aminolaevulinic acid patch-photodynamic therapy in the treatment of actinic cheilitis. Photodermatol Photoimmunol Photomed 2017, 33, 306-310.

14. Buinauskaite E., Maciulaitis R., Buinauskiene J., Valiukeviciene S.: Topical photodynamic therapy of actinic keratoses with 5-aminolevulinic acid: randomized controlled trial with six months follow-up. J Dermatolog Treat 2014, 25, 519-522.

15. Serra-Guillén C., Nagore E., Bancalari E., Kindem S., Sanmartín O., Llombart B., et al.: A randomized intraindividual comparative study of methyl-5-aminolaevulinate versus 5-aminolaevulinic acid nanoemulsion (BF-200 ALA) in photodynamic therapy for actinic keratosis of the face and scalp. Br J Dermatol 2018, 179, 1410-1411.

16. Ko D.Y., Kim K.H., Song K.H.: Comparative study of photodynamic therapy with topical methyl aminolevulinate versus 5-aminolevulinic acid for facial actinic keratosis with long-term follow-up. Ann Dermatol 2014, 26, 321-331.

17. O'Mahoney P., Haigh N., Wood K., Brown C.T.A., Ibbotson S., Eadie E.: A novel light source with tuneable uniformity of light distribution for artificial daylight photodynamic therapy. Photodiagnosis Photodyn Ther 2018, 23, 144-150. 
18. Kessels J.P.H.M., Kreukels H., Nelemans P.J., Roozeboom M.H., van Pelt H., Mosterd K., et al.: Treatment of superficial basal cell carcinoma by topical photodynamic therapy with fractionated 5-aminolaevulinic acid $20 \%$ vs. two-stage topical methyl aminolaevulinate: results of a randomized controlled trial. Br J Dermatol 2018, 178, 1056-1063.

19. Yazdanyar S., Zarchi K., Jemec G.B.E.: Pain during topical photodynamic therapy - comparing methyl aminolevulinate (Metvix ${ }^{\circledast}$ ) to aminolaevulinic acid $\left(\right.$ Ameluz $\left.^{\circledR}\right)$ : an intra-individual clinical study. Photodiagnosis Photodyn Ther 2017, 20, 6-9.

Received: 2.01 .2019

Accepted: 31.03 .2019

Otrzymano: 2.01.2019 r.

Zaakceptowano: 31.03.2019 r.

How to cite this article

Bartosińska J., Gerkowicz A., Niewiedzioł M., Szczepanik-Kułak P., Kwaśny M., Krasowska D.: Application of photodynamic therapy with the use of superluminescent light-emitting diode (sLED) lamp in actinic keratosis. Dermatol Rev/Przegl Dermatol 2019, 106, 372-383.

DOI: https://doi.org/10.5114/dr.2019.88254 